\title{
Calling and Membership in Intrinsic Motivation-based Leadership for Increasing Organizational Commitment and Productivity
}

\author{
Nadjib Usman ${ }^{1}$, Romi Ilham ${ }^{2}$ and Agus Samekto ${ }^{3}$ \\ ${ }^{1}$ STIE Perbanas Surabaya, Indonesia, e-mail: nadjib@perbanas.ac.id \\ ${ }^{2}$ STIE Perbanas Surabaya, Indonesia, e-mail: romi_ilham@perbanas.ac.id \\ ${ }^{3}$ STIE Perbanas Surabaya, Indonesia, e-mail: agus@perbanas.ac.id
}

\begin{abstract}
This research aims to contribute about the impacts of calling and membership for lecturers as professional through spiritual leadership. The proposed research model was tested using partial least square and 327 valid questionnaires were collected. According to the literature review and analytical technique, we concluded that spiritual leadership has a strong impact on organizational commitment and productivity, calling and membership appears to be a better mediator in the relationship between spiritual leadership with organizational commitment and productivity. Keywords: spiritual, calling, membership, organizational commitment, productivity.
\end{abstract}

\section{Introduction}

In order to improve the quality of the national education system in accordance with the vision of the Indonesian nation which reads "the realization of an Indonesian society that is peaceful, democratic, just, competitive, advanced and prosperous, in the container of the Republic of Indonesia which is supported by Indonesian people who are healthy, independent, faithful fearful and noble, love the motherland, legal and environmental awareness, master science and technology, and have a high work ethic and discipline". Higher education as part of system national education in Indonesian has a strategic role in educating the nation's life and advancing science technology by observing and applying the humanities value as well as the sustainable culture and empowerment of the nation. Currently the number of universities in Indonesia reaches 3,151 universities, the role of calling and membership in higher education must be done immediately, by the reason of low number of research and the declining spirit of teaching.

Calling is an extraordinary calling of the soul to get the meaning and purpose of life in making a change by serving others. The term calling has long been used to define the characteristics of a professional (F Markow \& Klenke, 2005). Professionals generally have special skills in behaving, ethics in serving, having an obligation to maintain their profession, commitment to their fields, dedicated to work and strong commitment to their careers (Ilham, 2012).

Membership as a basic human need that is to be understood and wanted to be appreciated (L. W. Fry, 2005). Having a feeling of wanting to be understood and wanting to be appreciated is an important issue in reciprocal relationships and social relations interactions (Samekto, Ilham, Djuwari, \& Effendi, 2017). The challenge for leaders in learning organizations is how to develop a sense of calling and membership in their work through work involvement and goal identification (Jay Galbraith, 1977). For realize Republic of Indonesia's strategic vision can be done well, the role of leaders in developing the spirit of calling and membership in human resources of higher education must have a superior quality leadership style, especially for lecturers as professional educators. (Liberty \& Prewitt, 1999).

Leadership that can motivate intrinsically to foster a feeling of calling and membership is spiritual leadership (L. W. Fry, 2003). Leadership that can motivate intrinsically so as to foster a feeling of calling and membership is spiritual leadership, where the spiritual leadership system has a sub system of altruistic love, hope and vision that can create an increase in workplace spirituality which includes feelings of calling and membership (L. W. Fry, 2004). In this study will analysis the development of workplace spirituality in the form of calling and membership of the spiritual leadership system to 
increase organizational commitment and productivity of lecturers in private universities in of Indonesia.

Workplace Spirituality. The feeling of calling and membership are two aspects needed in the workplace spirituality (Fleischman, 1989). Workplace spirituality is a new concept in organizational management and behavior models, especially organizational culture. This concept has actually been described in the concepts of organizational behavior such as values, ethics, and so on (Piryaei \& Zare, 2013). According to Robbins, (2013) said Workplace spirituality recognizes that people have an inner life that nourishes and is nourished by meaningful work that takes place in the context of community. Organizations that promote a spiritual culture recognize that people have both mind and a spirit, seek to find meaning and purpose in their work, and desire to connect with other human being and be part of community". Calling is an extraordinary calling of the soul to get the meaning and purpose of life in making a change by serving others (F Markow \& Klenke, 2005). There are three characteristics of calling, firstly the feeling that the work done is very important to him, secondly the feeling that the work done can give a positive change in his life, and the third is the feeling that the work activity is personally meaningful to him (L. W. Fry, 2003).

Membership as a basic human need that is to be understood and wanted to be appreciated (L. W. Fry, 2005). Having a feeling of wanting to be understood and wanting to be appreciated is an important issue in reciprocal relationships and social relations interactions. (Ilham, 2018b). There are two characteristics of membership, firstly the feeling of wanting to be understood in the community of the organization, the two feelings of wanting to be appreciated in the organizational community (L. W. Fry, 2003). In the work environment, everyone often combines the values they have so they feel they are part of a large organization and are interconnected with each other's interactions (Pfeffer, 2003).

Leadership as Motivation. Motivation is a process that determines the level of activity, intensity, consistency, and general direction of human behavior (Liang, Wang, Wang, \& Xue, 2018). There are two types of motivation, intrinsic motivation and extrinsic motivation. Intrinsic motivation is the motivation that becomes active or functioning, there is no need for external stimuli, because in everyone there is an urge to do something. Thus, the behavior of a person caused by his own will is not an external drive. While extrinsic motivation is active and functioning motivation due to encouragement or external stimuli. The desired goal of behavior driven by extrinsic motivation lies beyond that behavior (Ilham, 2018b). According to Fry, (2003) spiritual leadership is the formation of values, attitude, behavior needed to motivate yourself and others intrinsic motivation so as to achieve a sense of spiritual survival through calling and membership. The characteristics of spiritual leadership are vision, altruistic love and hope / faith. Spiritual leadership is indispensable for a change and continuity of learning organization.

The characteristics of spiritual leadership are vision which is a picture in the future that will be implicit or very explicit because of why someone struggles to reach the future " (Kotler \& Keller, 2015), Altruistic Love which is the reason why organization exists and is a basis for making vision. This defines what an organization stands for in the real sense and defines the corporate culture, the value of the company and the reason why the company exists. Culture exists in a set of moral values, assumptions, understanding and awareness of the way of thinking that helps-help fellow members and teach new members correctly (Schein, 1990), and Hope / Faith is "certainty of what is expected, sanctions from something not seen ". Trust is more than just hope or hope for something you want. This is a sanction that cannot be proven by physical evidence. Hope is a desire for a hope that is fulfilled. People who have trust or hope have a purpose where they will go, and how to achieve it, they will be able to face resistance, fortress and suffering in achieving their goals (MacArthur, 1998). Thus, trust or hope is the basis of the establishment of the vision / goal / mission of the organization that will be fulfilled.

Organizational Commitment. Organizational commitment as a person who has feelings of calling and membership that will become interconnected for more loyalty, and wants to stay in an organization 
that has a culture based on altruistic love (Osa \& Amos, 2014). Fry, (2003) This can be demonstrated by having a feeling of being a family in an organization, having a feeling that the problems in the organization is a common problem, having a happy feeling and proud to be able to develop a career in the organization, and have a feeling of pride by telling others about the organization as a pleasant place to work (Meyer \& Allen, 1991). The characteristics of organizational commitment are, first is the feeling of being a family in this organization, second is the feeling that the problems that are owned by the organization are a common problem, third is feeling happy and proud to have a career in this organization and fourth is telling others that / about this organization is a fun place to work (Piryaei \& Zare, 2013). Robbins (2013), it is defined that high employee involvement means taking part in someone's work, while high organizational commitment means taking sides with the organization that recruits the individual. In higher education organizations, lecturers are professionals who are dealing directly with students, so the lecturer in carrying out his duties as an educator can carry out policies with specific goals and has a strong commitment to the school where he works.

Productivity. Productivity is human desire and effort to always improve the quality of life and livelihood in all fields (Turban, McLean, \& Wetherbe, 2001). Work productivity is the ability of employees to produce compared to the input used, an employee can be said to be productive when able to produce research work (Elfindri, Supriadi Rustad, Nizam, 2015). Characteristics of productivity are, first feel busy working until there is no time, both quality of work is a top priority in the work, third give the best effort in every job and fourth get maximum results with resource efficiency (L. W. Fry, 2003).

\section{Research Methodology}

This research is a quantitative research to determine the development of the most significant calling and membership model on organizational commitment and lecturer productivity in Indonesia. The population in this study were lecturers at 15 private universities in East Java - Indonesia, with the sample requirement is a lecturer who has a minimum position of expert assistant and a minimum of 2 years of work. Analysis technique using Partial Least Square (PLS) as data analysis tool, because Smart PLS based covariance, then the number of respondents above 75 is enough to produce good analysis (Joseph F. Hair, Ringle, \& Sarstedt, 2011). With the following steps: 1. Prepare the path diagram, 2. Determine the structural equation, 3. Confidentiality Criteria (convergent validity, discriminant validity, composite reliability, R-Squared). The variables in this study consist of demographic, manifest, exogenous and endogenous variables. The variables used in this study as follows: 1. Variables of demographic characteristics (Sex, Functional Position), 2. Exogenous variables (Spiritual Leadership (vision, altruistic love, hope)), 3. Endogen intervening variable (Calling, Membership), 4. Endogen Variables (Organizational Commitment, Productivity), 5. Manifest Variables, manifest variables are variables used to explain and measure latent variables, in this study is a questionnaire associated with latent variables.

\section{Result and Discussion}

The survey conducted on 375 respondents spread evenly in 15 private universities with each of the questionnaires distributed as many as 25 packages for each private university. The survey results show that of the 375 respondents expected, the results were 327 respondents who filled out and could be used. The following table 1 is the distribution of questionnaire data at 15 private universities. 
Table 1. Respondent

\begin{tabular}{lll}
\hline No & University & Respondent \\
\hline 1 & STIE Perbanas Surabaya & 25 respondents \\
\hline 2 & Universitas Tujuh Belas Agustus Surabaya & 23 respondents \\
\hline 3 & Universitas Darul 'Ulum, Jombang & 22 respondents \\
\hline 4 & Universitas Muhammadiyah Sidoarjo, Sidoarjo & 25 respondents \\
\hline 5 & Universitas 17 Agustus 1945 Banyuwangi, Banyuwangi & 23 respondents \\
\hline 6 & Universitas Muhammadiyah Gresik, Gresik & 23 respondents \\
\hline 7 & Universitas Merdeka Ponorogo, Ponorogo & 23 respondents \\
\hline 8 & Universitas Abdurachman Saleh, Situbondo & 22 respondents \\
\hline 9 & STIKES Bina Sehat Ppni Mojokerto, Mojokerto & 21 respondents \\
\hline 10 & Universitas Soerjo, Ngawi & 18 respondents \\
\hline 11 & Universitas Islam Blitar, Blitar & 19 respondents \\
\hline 12 & Universitas Bojonegoro, Bojonegoro & 18 respondents \\
\hline 13 & Universitas Bondowoso, Bondowoso & 19 respondents \\
\hline 14 & Universitas Islam Indonesia Madiun, Madiun & 22 respondents \\
\hline 15 & Universitas Islam Madura, Madura & 24 respondents \\
\hline
\end{tabular}

Figure 1. PLS Model

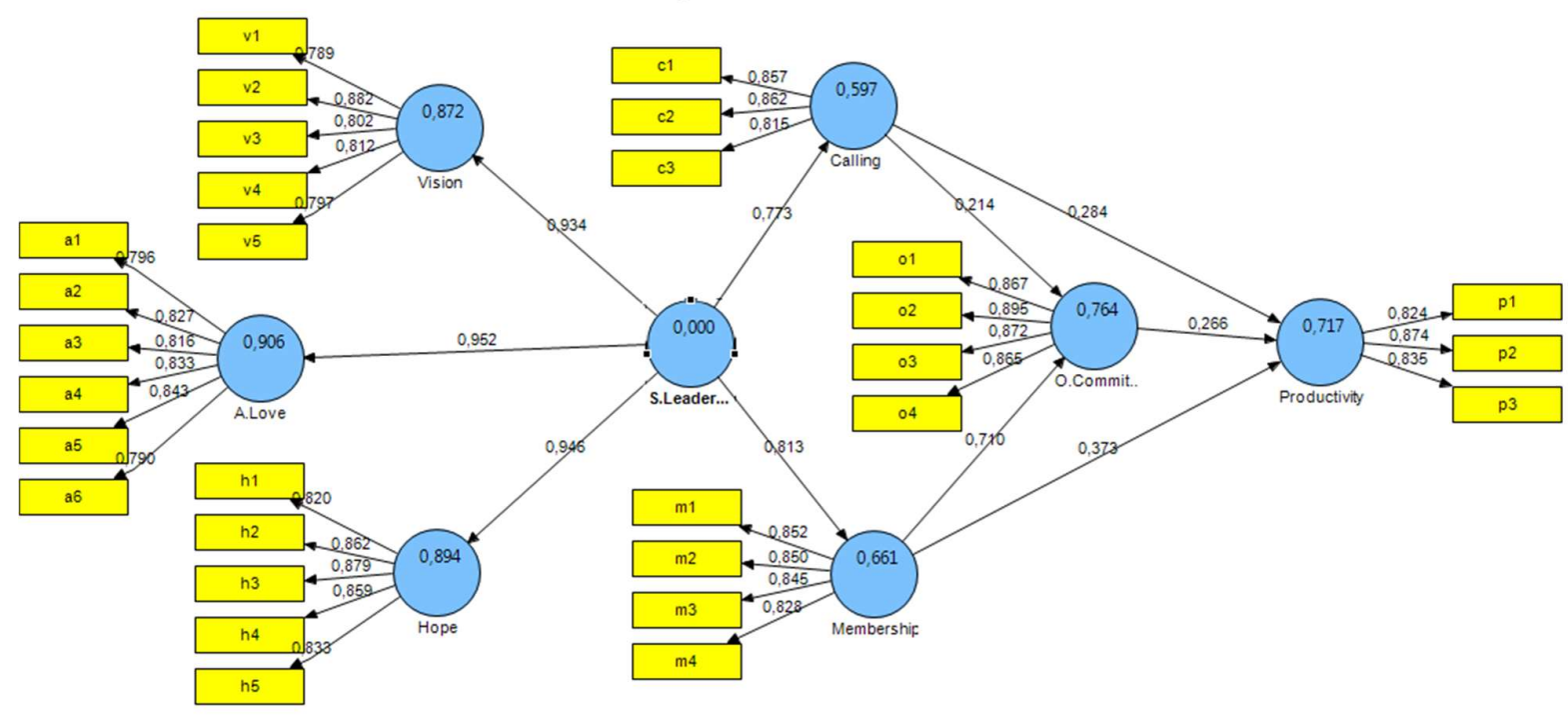


Table 2. Cross Loading Factor

\begin{tabular}{|c|c|c|c|c|c|c|c|}
\hline & A.Love & Calling & Hope & Membership & O.Commitment & Productivity & Vision \\
\hline a1 & 0,796372 & 0,640113 & 0,649952 & 0,597059 & 0,618089 & 0,542448 & 0,672733 \\
\hline $\mathrm{a} 2$ & 0,827024 & 0,622887 & 0,680971 & 0,628107 & 0,678006 & 0,638716 & 0,705923 \\
\hline a3 & 0,816486 & 0,645251 & 0,678049 & 0,630879 & 0,655252 & 0,644654 & 0,649679 \\
\hline $\mathrm{a} 4$ & 0,832772 & 0,557784 & 0,699637 & 0,598369 & 0,628197 & 0,615395 & 0,663616 \\
\hline a5 & 0,842581 & 0,614541 & 0,703993 & 0,662918 & 0,694606 & 0,661173 & 0,709110 \\
\hline $\mathrm{a} 6$ & 0,790451 & 0,577834 & 0,740640 & 0,650285 & 0,666044 & 0,593759 & 0,684281 \\
\hline $\mathrm{cl}$ & 0,679338 & 0,857053 & 0,695804 & 0,577720 & 0,594059 & 0,641443 & 0,610302 \\
\hline $\mathrm{c} 2$ & 0,619690 & 0,862115 & 0,609044 & 0,601846 & 0,630363 & 0,631095 & 0,552630 \\
\hline c3 & 0,587565 & 0,815363 & 0,619382 & 0,605775 & 0,585026 & 0,591119 & 0,551371 \\
\hline h1 & 0,778011 & 0,637739 & 0,820483 & 0,703816 & 0,714225 & 0,645894 & 0,773445 \\
\hline h2 & 0,696396 & 0,598718 & 0,861701 & 0,653712 & 0,671617 & 0,625998 & 0,731319 \\
\hline h3 & 0,748758 & 0,700530 & 0,878626 & 0,653974 & 0,670692 & 0,626242 & 0,710100 \\
\hline h4 & 0,710560 & 0,641942 & 0,858812 & 0,646198 & 0,660188 & 0,694542 & 0,663805 \\
\hline h5 & 0,661344 & 0,651235 & 0,833012 & 0,636045 & 0,610528 & 0,588860 & 0,646898 \\
\hline $\mathrm{m} 1$ & 0,626556 & 0,606856 & 0,648504 & 0,852383 & 0,737136 & 0,656339 & 0,645354 \\
\hline $\mathrm{m} 2$ & 0,639948 & 0,511413 & 0,615670 & 0,850017 & 0,727900 & 0,648703 & 0,605107 \\
\hline $\mathrm{m} 3$ & 0,678558 & 0,626590 & 0,699836 & 0,844618 & 0,774415 & 0,686686 & 0,685180 \\
\hline $\mathrm{m} 4$ & 0,645821 & 0,626634 & 0,648969 & 0,827870 & 0,661134 & 0,711012 & 0,620996 \\
\hline o1 & 0,715126 & 0,625520 & 0,692407 & 0,714516 & 0,866738 & 0,646958 & 0,725426 \\
\hline o2 & 0,719399 & 0,666097 & 0,682591 & 0,754059 & 0,895249 & 0,697095 & 0,690664 \\
\hline 03 & 0,687650 & 0,596683 & 0,686623 & 0,777124 & 0,872495 & 0,724016 & 0,686696 \\
\hline $\mathrm{o} 4$ & 0,691127 & 0,610109 & 0,681476 & 0,763357 & 0,865108 & 0,689897 & 0,673279 \\
\hline $\mathrm{p} 1$ & 0,597971 & 0,605248 & 0,605166 & 0,631863 & 0,659980 & 0,824338 & 0,556230 \\
\hline p2 & 0,697656 & 0,686199 & 0,675953 & 0,710243 & 0,695962 & 0,874468 & 0,672593 \\
\hline p3 & 0,610282 & 0,567857 & 0,612857 & 0,685887 & 0,642090 & 0,834505 & 0,568298 \\
\hline v1 & 0,608937 & 0,485970 & 0,612371 & 0,531862 & 0,576984 & 0,493490 & 0,789019 \\
\hline v2 & 0,737504 & 0,586162 & 0,724364 & 0,634870 & 0,707832 & 0,623047 & 0,882364 \\
\hline v3 & 0,642223 & 0,538204 & 0,648525 & 0,594504 & 0,594812 & 0,539207 & 0,801854 \\
\hline $\mathrm{v} 4$ & 0,701088 & 0,592828 & 0,714342 & 0,686423 & 0,683958 & 0,645844 & 0,811844 \\
\hline v5 & 0,704686 & 0,555074 & 0,686739 & 0,643698 & 0,664669 & 0,594538 & 0,797392 \\
\hline
\end{tabular}

Source: Primary Data Processed, 2017

After determining the variables that are influential, the modelling process is done as shown in figure 1 using the smart pls application. From the results of table 2 shows all the loading factor values $>0.6$ so that all indicators are declared valid or can measure each variable. Altruistic love is a latent variable which is measured by 6 (six) indicators, namely the level of leadership concern for employees (a1), the ability of leaders to pay attention and hear the aspirations of employees (a2), the ability of leaders to communicate with employees (a3), the ability of leaders to be trusted and loyal to employees (a4), the ability of leaders to forgive unintentional mistakes made by employees (a5), and leadership behavior not to show leadership arrogance (a6). Based on table 2 indicator variables The ability of leaders to forgive unintentional mistakes made by employees (a5) is an indicator variable that is most capable of measuring altruistic love variables. Altruistic love is a sense of wholeness, harmony, mutual forgiveness and prosperity that is produced through caring, caring, and appreciating for yourself and others (Snyder \& Ingram, 2000).

Calling is a latent variable which is measured by 3 (three) indicators, namely the work done is very important for him (c1), the work done can give a positive change in life (c2) and work activities are personally meaningful to him (c3). Based on table 2 the work indicator variable can give a positive 
change in life (c2) is the variable that is most capable of measuring calling variables. Calling is an experience of transcendence or how a person makes a difference through service to others, many people not only look for competencies to bring about positive change in themselves through their work but also the sense of working has several meanings or social values (Giacalone \& Jurkiewicz, 2015).

Hope is a latent variable that is measured by 5 (five) indicators, namely the expectations of employees at the leadership to do the best for the organization and ensure that the organization has completed the organizational mission (h1), employee expectations on the leadership to help the organization become successful because it has a sense of responsibility on organization (h2), employee expectations for the leader to have responsibility for the organization (h3), employee expectations for the leader to make goals in carrying out each job (h4) and employee expectations for the leadership so that leaders sacrifice for the survival of the organization (h5). Based on table 2 the indicator variables of employee expectations on the leadership to have responsibility for the organization (h3) are indicator variables that are most able to measure the hope variable. People with hope / confidence have a vision of where they will go, and are responsible for achieving goals; they are willing to face opposition and responsibility in the face of difficulties and suffering, to achieve their goals (MacArthur, 1998).

Membership is a latent variable which is measured by 4 (four) indicators, namely the employee's desire for the leader to understand the employee's problems (m1), the employee's desire for the leader to respect employees and their work $(\mathrm{m} 2)$, the desire of the employees to understand the employee's problems (m3) and desires employees so that the campus values employees and their work (m4). Based on table 2 the indicator variables of employee desires so that leaders understand employee problems $(\mathrm{m} 1)$ are indicator variables that are most able to measure membership variables. Building a social culture / organization in which leaders and followers have genuine care, attention, and appreciation for themselves or others, thus generating a sense of membership and understanding and respect (L. W. Fry, 2003).

Organizational Commitment is a latent variable which consists of 4 (four) indicators, namely feeling to be a family in this organization (o1), having a feeling that the problems possessed by the organization are a common problem ( 02$)$, Feeling happy and proud to have a career in this organization (03) and tell others that / about this organization as a pleasant place to work (04). Based on table 2 the indicator variable has a feeling that the problem that is owned by the organization is a shared problem (o2) is the variable that is most able to measure organizational commitment. That the organizational environment in the 21 st century is chaotic and requires rapid response from learning organizations that are very committed, productive, and intrinsically motivated by teams that have cooperation in solving problems together (Ancona, Kochan, Scully, Maanen, \& Westney, 1999).

Productivity is a latent variable which is measured by 3 (three) indicators namely the feeling of everyone busy working ( 1 1), the feeling of work quality is the main quality (p2), the feeling of working passionately (p3). Based on table 2 the indicator variable feeling of work quality is the main quality (p2) is an indicator variable that is most able to measure productivity variables. Professionals generally have expertise in specialized fields of knowledge, ethics that focus on selfless service to customers, the obligation to maintain quality standards in the profession, dedication to their work, is a strong commitment in their careers (House \& Robert J., 1976).

Vision is a latent variable that is measured by 5 (five) indicators, namely the level of commitment and ability of the leadership to convey the vision of the organization clearly to employees (v1), the ability of the leadership in applying vision statements so that they can exclude the best abilities of employees (v2), leadership skills in inspire employees to have performance in accordance with the organization's vision (v3), the ability of leaders to convince the organization's vision for each employee (v4) and the ability of leaders to motivate employees to be more advanced (v5). Based on table 2 the indicator variables of the ability of the leadership in applying vision statements so that 
they can exclude the best ability of employees (v2) are indicator variables that can measure vision variables (Greenleaf, 1979).

Table 3. Value AVE and Composite Reliability

\begin{tabular}{llllll}
\hline & AVE & Composite Reliability & R Square & Cronbachs Alpha & \\
\hline A.Love & 0,668848 & 0,923735 & 0,906228 & 0,900834 & Valid \\
\hline Calling & 0,714199 & 0,882245 & 0,597215 & 0,799642 & Valid \\
\hline Hope & 0,723834 & 0,929064 & 0,894023 & 0,904457 & Valid \\
\hline Membership & 0,711958 & 0,908136 & 0,661024 & 0,865138 & Valid \\
\hline O.Commitment & 0,765591 & 0,928885 & 0,763649 & 0,897898 & Valid \\
\hline Productivity & 0,713542 & 0,881906 & 0,716890 & 0,799077 & Valid \\
\hline S.Leadership & 0,610981 & 0,961659 & & 0,957358 & Valid \\
\hline Vision & 0,667802 & 0,909372 & 0,872328 & 0,875121 & Valid \\
\hline
\end{tabular}

Source: Primary Data Processed, 2017

From the results of table 3 shows all AVE values $>0.5$ and all composite reliability values $>0.7$ so that all indicators are declared reliable or can measure each of the latent variables well. After unidimensional testing each latent variable by using Confirmatory Factor Analysis, the next step is to do Structural Equation Modeling (SEM) analysis with a full model. Structural Equation Modeling analysis testing is carried out using a variance-based SEM method which is often referred to as SEMPLS. This method was chosen by the researcher with the justification of the researcher that this research is explorative and the assumption in the SEM-PLS method is nonparametric, which does not require many assumptions, such as covariance-based SEM which is often called SEM which requires many assumptions because it is parametric (Monecke, A. and Leisch, 2012). The hypothesis raised in this study is:

H1: Calling influences organizational commitment

$\mathrm{H} 2$ : Calling affects productivity

H3: Membership influences organizational commitment

H4: Membership affects productivity

H5: Organizational Commitment affects productivity

H6: Spiritual Leadership affects Altruistic love

H7: Spiritual Leadership affects calling

H8: Spiritual Leadership influences hope

H9: Spiritual Leadership affects membership

H10: Spiritual Leadership affects vision

The model of measuring the significance of the indicator on the construct can measured through loading factors and and compare t-count values with t-tables using the following hypothesis:

$\mathrm{H} 0: \lambda \mathrm{i}=0$ (loading factor is not significant in measuring latent variables)

$\mathrm{H} 1: \lambda \mathrm{i} \neq 0$ (loading factor is significant in measuring latent variables)

The results of the SEM variance test or SEM-PLS are presented in Figure 2 as follows: 
Figure 2. SEM Bootstrap

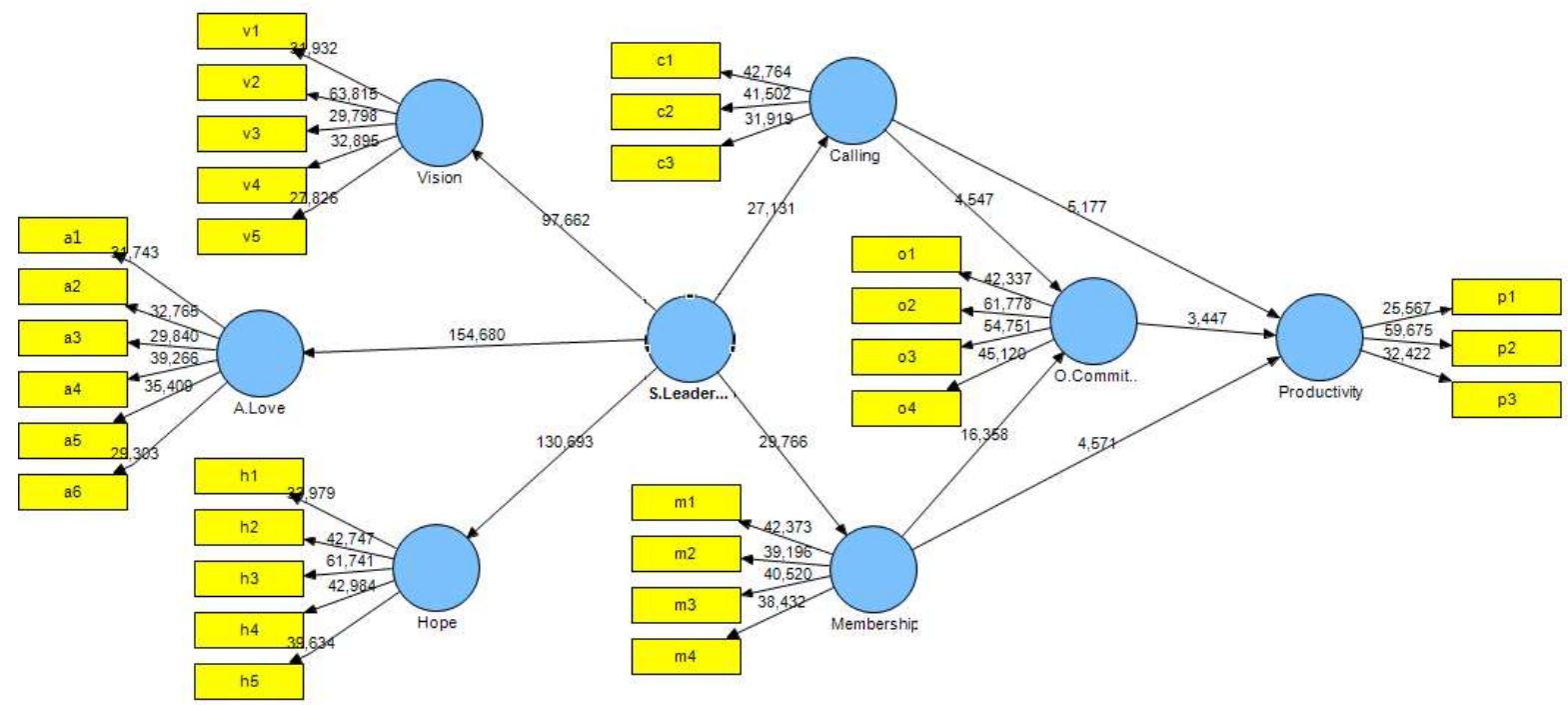

Inner Model. After a Confirmatory Factor Analysis and an indicator can measure well the latent variables, then the inner model analysis is performed. Inner model analysis is done to determine the relationship between latent variables and to conclude the research hypothesis is accepted or rejected. The test criteria for hypothesis testing are, if the t-statistics value $>1.96$ with an alpha assumption (5\% error tolerance) then it can be concluded that the relationship between the two latent variables is significant (accepted hypothesis) and vice versa. The results of the inner model analysis for the latent variables are presented in the table as follows:

Table 4. Inner Model

\begin{tabular}{|c|c|c|c|c|}
\hline & $\begin{array}{l}\text { Original Sample } \\
\text { (O) }\end{array}$ & $\begin{array}{l}\text { Sample Mean } \\
\text { (M) }\end{array}$ & $\begin{array}{l}\text { T Statistics } \\
(|\mathrm{O} / \mathrm{STERR}|)\end{array}$ & Results \\
\hline $\begin{array}{l}\text { Calling -> } \\
\text { O.Commitment }\end{array}$ & 0,214453 & 0,216766 & 4,546692 & Significant \\
\hline Calling -> Productivity & 0,283751 & 0,281659 & 5,176593 & Significant \\
\hline $\begin{array}{l}\text { Membership -> } \\
\text { O.Commitment }\end{array}$ & 0,709606 & 0,707312 & 16,358174 & Significant \\
\hline $\begin{array}{l}\text { Membership -> } \\
\text { Productivity }\end{array}$ & 0,372869 & 0,372425 & 4,571213 & Significant \\
\hline $\begin{array}{l}\text { O.Commitment -> } \\
\text { Productivity }\end{array}$ & 0,265555 & 0,267376 & 3,446597 & Significant \\
\hline S.Leadership -> A.Love & 0,951960 & 0,951876 & 154,680442 & Significant \\
\hline S.Leadership -> Calling & 0,772797 & 0,773226 & 27,130896 & Significant \\
\hline S.Leadership $->$ Hope & 0,945528 & 0,945555 & 130,693082 & Significant \\
\hline $\begin{array}{l}\text { S.Leadership -> } \\
\text { Membership }\end{array}$ & 0,813034 & 0,812897 & 29,766189 & Significant \\
\hline S.Leadership -> Vision & 0,933985 & 0,933929 & 97,661671 & Significant \\
\hline
\end{tabular}

Source: Primary Data Processed, 2017

The results showed in table 4 that there was a direct influence between calling on organizational commitment at private universities. The higher the feeling of calling possessed by the lecturer, the higher the organizational commitment possessed by each lecturer. Fry, (2003) which states that 
spiritual leadership is the formation of values, attitude, behavior needed to motivate yourself and others in the intrinsic motivation to achieve a sense of spiritual survival through the calling / meaning and membership so that the impact on the control of organizational commitment, productivity and firm performance. Fairholm, (1998) which states that organizational commitment is the employees who have a sense of calling and membership then be interconnected to more loyal (loyalty), and wanted to stay (commitment) to an organization that has a culture based on the values of love (altruistic love). Fry, (2004) defines calling as a positive inspiration in the spirit of being responsible for work. The professional attitude that each employee has based on feeling calling will increase the feeling of being more meaningful to others and the organizational environment and himself (Roy F. Baumeister, 1991). People will do anything for a calling that is very different from a job or career (Roy F. Baumeister, 1991). When a job is seen as a spiritual calling (calling) and not a job that can take on a new meaning (Davidson \& Caddell, 1994; Hoffman \& Novak, 1996). So strong spiritual calling (calling) and spiritual relationship with the work that goes beyond professionalism or salary will result in the relationship, and thus would be a commitment to a job (Frank Markow \& Klenke, 2005). In several researches, it has been shown that employee commitment is positively correlated with several organizational outcomes. For example, employees who are committed to the organization will show a lower level in negative behaviors such as absenteeism or turnover (Ghalandari, Ghorbani, Jogh, Imani, \& Nia, 2012).

Based on the results showed that the feeling of calling lecturers on private universities has a significant effect. This indicates that feeling of calling is owned by most private university lecturers therefore influences organizational commitment.

H1: Calling affects organizational commitment

$\mathrm{H} 2$ : Calling affects productivity

The results show that there is a direct influence between calling on productivity and organizational commitment at private university lecturers in East Java. The higher the feeling of calling possessed by the lecturer, the higher the productivity and organizational commitment possessed by each lecturer. L. W. Fry, (2003) which states that the calling impact on the control of organizational commitment, productivity and firm performance. Fairholm, (1998) which states that productivity and continuous improvement are people who have hope / confidence in the vision of the organization and people who have calling and membership will do anything to pursue a vision to improve themselves and become more productive. Frank Markow \& Klenke, (2005) define calling as a positive inspiration in the spirit of being responsible for work. The professional attitude that each employee has based on feeling calling will increase the feeling of being more meaningful to others and the organizational environment and himself (Roy F. Baumeister, 1991). People will do anything for a calling that is very different from a job or career, when a job is seen as a calling and not a job that can take on a new meaning (Davidson \& Caddell, 1994; Hoffman and Novak, 1996). Therefore calling a strong soul (calling) and spiritual relationships with work that goes beyond professionalism or salary will lead to deep relationships, and thus commitment to one job (F Markow \& Klenke, 2005). Nyhan, (2000), the calling of the soul and trust between employees and leaders can lead to productivity, in this case the employee in question is a lecturer. Nyhan, (2000) found a strong relationship between interpersonal trust in organization and organizational commitment.

Based on the results showed that the feeling of calling lecturers of private universities in East Java has a significant effect. This indicates that feeling calling is owned by most private university lecturers in East Java, which affects productivity and organizational commitment.

H3: Membership affects organizational commitment.

H4: Membership affects productivity

The results show there is a direct influence between membership on organizational commitment in private university lecturers in East Java. The higher the feeling of membership owned by the lecturer then the higher the organizational capacity of each lecturer. L. W. J. Fry, (2009) which states membership have an impacts in controlling organizational commitment, productivity and firm 
performance. (Hwang \& Cha, 2018) which states that organizational commitment is employees who have a feeling of membership then become interconnected to be more loyal (loyalty) and want to stay (commitment) in an organization that has a culture based on the values of love (altruistic love). According to William in L. W. Fry, (2004) the founder of modern psychology defines membership as a basic human need that is to be understood and wanted to be appreciated. Having a feeling of wanting to be understood and wanting to be appreciated is an important issue in reciprocal relationships and social relations interactions. (Ferguson \& Milliman, (2008) stated "We grow greater, longer lived, more meaningful in proportion as we identify ourselves with the larger social life that surrounds us", which means "We grow bigger, live longer, be more meaningful in proportion as we identify with the broader social life that surrounds us ". The feeling of membership is one of the feelings of spirituality in the work environment (workplace spirituality) which is very important to be developed so that the social relations between lecturers can be interwoven harmoniously, shown based on the results of research that the membership influence is quite significant. This identifies that the membership is owned by most private university lecturers in East Java so that it influences organizational commitment and productivity. And the facts in the field proved that there is strong cooperation, including in the field of research and low turnover of lecturers.

H5: Organizational Commitment affects productivity.

The results showed that there was a direct influence between Organizational Commitment on productivity at private university lecturers in East Java. The higher the feeling of Organizational Commitment held by the lecturer, the higher the productivity of each lecturer. Organizational commitment has a significant positive influence on employee performance, normative commitment leaves the strongest effect on average performance, compared to affective commitment and ongoing commitment (Ghorbanpour, Dehnavi, \& Heyrani, 2014). Organizational commitment is an attitude that reflects the extent to which an individual knows and is bound to his organization. Employees who feel more committed to the organization have reliable habits, plan to stay longer in the organization, and devote more effort to work (Griffin, 2008). Performance is the work quality and quantity achieved by an employee in carrying out his duties in accordance with the responsibilities assigned to him (Osa \& Amos, 2014). Based on the results of the study that the influence of organizational commitment is quite significant. This identifies that organizational commitment is owned by most private university lecturers in East Java, which affects productivity.

H7: Spiritual Leadership affects calling.

H9: Spiritual Leadership affects membership.

The results showed that there was a direct influence between spiritual leadership on calling and membership at universities in East Java. The higher the spiritual leadership possessed by the leader, the higher the calling / meaning possessed by each lecturer. L. W. Fry, (2003) who stated that spiritual leadership is the formation of values, attitude, behavior needed to motivate themselves and others intrinsic motivation to reach a sense of spiritual survival through calling and membership. In spiritual leadership, calling is a transcendent Vision from a form of lecturer responsibility towards students. This allows the lecturer to show intrinsic motivation through calling "doing what it takes" to "spread the organization message" which is related to quality of life and integrity (L. W. J. Fry \& Ph, 2006). A leader who has the nature of spiritual leadership must have the nature of trust / loyalty, forgiveness / acceptance / gratitude, integrity, honesty, courage, humanity, empathy / compassion, patience / weakness / endurance, excellent and fun. And based on the characteristics possessed by the spiritual style of leadership can lead to a sense of spiritual survival. Calling and membership are two aspect of workplace spirituality that is needed in the spiritual dimension of survival, the term calling has long been used to define the characteristics of a professional, meanwhile the term membership can be defined as a basic human need, which is to be understood and wanted to be appreciated.

Professionals generally have special expertise in body language behavior, ethics in serving customers, an obligation to maintain their profession, commitment to their fields, dedicated to work and strong commitment to their careers. Jay Galbraith, (1977) states that the challenge for leaders in learning 
organizations is how to develop a sense of calling and membership in their work through work involvement and goal identification. With the leadership's spiritual style, it can increase meaningful and meaningful feelings (personal meaning) in carrying out work. Personal meaning is also a source of personal motivation to influence others and the environment (Sosik \& Godshalk, 2000).

According to Roy F. Baumeister, (1991) which distinguishes a call of the soul in work (call for work) by working (work) is the feeling of someone who considers working is only related to making money, because by working it will make money, and often does not give feeling of personal meaning and satisfaction in work. While the calling of the soul (calling) can be indicated as an individual's perception in determining the goals of life, especially in work. A Professional tends to have feeling calling / meaning at work, such as a doctor, teacher, social worker, leader. They have a dedication in their work and a strong commitment to career (Davidson \& Caddell, 1994).

More than that, calling is not only a feeling of commitment of a professional to his work but an experience transcendent for how to make a change and get meaning in achieving life goals (L. W. Fry, 2003). Having a feeling of wanting to be understood and wanting to be appreciated is an important issue in reciprocal relationships and social relations interactions. In a work environment, everyone combines their values so they feel they are part of a large organizational community and relate to one another (Pfeffer, 2003). Through the leadership's spiritual leadership style, it can increase the feeling of membership, so that employees can relate to each other with positive social relationships among fellow members of the organization and everyone feels more valued and understood as a whole person. So spiritual leadership underlies the birth of one spiritual survival dimension in the form of calling and membership.

H6: Spiritual Leadership affects Altruistic love.

H8: Spiritual Leadership influences hope.

H10: Spiritual Leadership affects vision

The results showed that there was a direct influence between Spiritual Leadership on altruistic love, hope, and vision in private university lecturers in East Java. The higher feeling of Spiritual Leadership held by the lecturer, the higher the altruistic love, hope and vision that is owned by each lecturer. Spiritual leadership aims to motivate and inspire employees through the creation of a vision, hope and culture based on altruistic values to produce workers who have organizational commitment and productivity (L. W. Fry, 2005). Altruistic love is a description of an organization's culture which is defined as a feeling of being intact, harmonious, prosperity through attention, care and appreciation for oneself and others (Thayib, 2013). Hope is a desire for a hope that is fulfilled. People who have trust or hope have a purpose where they will go, and how to achieve it, they will be able to face resistance, defense and suffering in achieving their goals (MacArthur, 1998; Wnuk, Marcinkowski, \& Fobair, 2012). Vision is a dimension that will appear implicitly or very clear (explicit) because of someone who is struggling to reach the Future (Kotler \& Keller, 2015). Vision has an important function in clarifying direction and purpose, namely, to simplify even thousands of decisions, then help to accelerate and streamline the actions of various people.

In a study of positive psychological feelings confirms that spiritual leadership characteristics consisting of vision, altruistic love and hope have the power to overcome four groups of bad influences that can interfere with feelings, namely: fear (anxiety, worry, apprehension), anger (hostility, resentment, envy, jealousy, hatred, sense of failure) (Seligman \& Csikszentmihalyi, 2000; Snyder \& Ingram, 2000). Based on the results of research that the spiritual leadership is influence of quite significant. This identifies that spiritual leadership is owned by most leaders of private university lecturers in East Java so that it influences altruistic love, hope and vision.

\section{Conclusion}

Every lecturer working in the organization has its own norms and values and different belief towards organization where he / she works. Sometimes organizational commitment differs from employee norms and values so any anytime employee join the organization, he / she should allow herself that 
either they can come up with them or not. Organizational commitment and leadership spiritual has strong and deep impact on the performance of the lecturer, that help employees to be satisfied themselves with organization and that cause to improve in the productivity of lecturer's (Ilham, 2018a).

Based on findings of this research we conclude that there is positive and significant correlation among Impact of leadership on lecturer's performance and productivity. From our study we found that leadership spiritual can create calling and membership soul, and that are important element which highly influences the lecturer performance (productivity) and organizational commitment. For future research the object is not just private university only but also including public university to find out and compare productivity and organizational commitment.

Acknowledgment. The authors wish to thank to God and to all my colleague in STIE Perbanas Surabaya Indonesia for the information regarding opportunities in research publications. This paper was supported and funded by the Research, Technology and Higher Education Ministry of Republic of Indonesian (RISTEKDIKTI).

\section{References}

Ancona, D. G., Kochan, T. A., Scully, M., Maanen, J. Van, \& Westney, D. E. (1999). Managing for the Future: Organizational Behaviour and Processes (3rd Ed). Boston: South-Western College Publishing.

Davidson, J. C., \& Caddell, D. P. (1994). Religion and the Meaning of Work. Journal for the Scientific Study of Religion, 33(2), 135. https://doi.org/10.2307/1386600

Elfindri, Supriadi Rustad, Nizam, D. (2015). Lecturer performances in indonesia higher education. International E-Journal of Advances in Education, I(1), 26-36. https://doi.org/http://dx.doi.org/10.18768/ijaedu.09134

Fairholm, G. W. (1998). Leadership as an exercise in virtual reality. Leadership \& Organization Development Journal, 19(4), 187-193. https://doi.org/10.1108/01437739810217160

Ferguson, J., \& Milliman, J. (2008). Creating effective core organizational values: A spiritual leadership approach. International Journal of Public Administration, 31(4), 439-459. https://doi.org/10.1080/01900690701590835

Fleischman, P. R. (1989). The healing spirit: Explorations in religion and psychotherapy. Cleveland: Paragon House.

Fry, L. W. (2003). Toward a theory of spiritual leadership. Leadership Quarterly, 14(6), 693-727. https://doi.org/10.1016/j.leaqua.2003.09.001

Fry, L. W. (2004). Spiritual Leadership Theory as a Source for Future Theory, Research, and Recovery for Workaholism. Research Companion to Working Time and Work Addiction. https://doi.org/10.4337/9781847202833.00025

Fry, L. W. (2005). Toward a Theory of Ethical and Spiritual Well-being, and Corporate Social Responsibility Through Spiritual Leadership. In , (Eds.), (pp. ). Information Age, 47-83. https://doi.org/spi

Fry, L. W. J. (2009). Spiritual Leadership Theory as a Paradigm for Organization Transformation and Development, 84(9720), 265-278.

Fry, L. W. J., \& Ph, D. (2006). Spiritual Leadership as an Integrating Paradigm for Positive Leadership Development Spiritual Leadership as an Integrating Paradigm for Positive Leadership Development. 2006 Gallup Leadership Summit, 76549(254), 1-24. https://doi.org/spi

Ghalandari, K., Ghorbani, M., Jogh, G., Imani, M., \& Nia, L. B. (2012). The Effect Of Emotional Labor Strategies On Employees Job Performance And Organizational Commitment In Hospital Sector: Moderating Role Of Emotional Intelligence In Iran. World Applied Sciences Journal, 17(3), 319-326. 
Ghorbanpour, Z., Dehnavi, H. D., \& Heyrani, F. (2014). Investigating The Effect of Organization Commitment on Performance of Auditors in The Community of Certified Accountants. Interdisciplinary Journal of Contemporary Research in Business, 5(10), 199-209.

Giacalone, R. A., \& Jurkiewicz, C. L. (2015). Handbook of Workplace Spirituality and Organizational Performance (3rd ed.). New York: Routledge M.E Sharpe.

Greenleaf, R. K. (1979). Servant leadership: A journey into the nature of legitimate power and greatness. Business Horizons (Vol. 22). New York: Paulist Press. https://doi.org/10.1016/00076813(79)90092-2

Griffin, R. W. (2008). Principles Of Management (1st ed.). New York: McGraw-Hill/Irwin; 1st edition (2008).

Hoffman, D. L., \& Novak, T. P. (1996). Marketing in Hypermedia Computer-Mediated Environments: Conceptual Foundations. Journal of Marketing, 60(3), 50. https://doi.org/10.2307/1251841

House, A. C., \& Robert J., F. (1976). Managerial process and organizational behaviour. Glenview: Scott, Foresman.

Hwang, I., \& Cha, O. (2018). Examining technostress creators and role stress as potential threats to employees' information security compliance. Computers in Human Behaviour, 81, 282-293. https://doi.org/10.1016/j.chb.2017.12.022

Ilham, R. (2012). Pengaruh Spiritual Leadership Terhadap Organizational Commitment Melalui Calling Dan Membership Pada Pt . Asuransi Takaful Keluarga. Jurnal Manajemen Teori Dan Terapan, April(1), 1-16.

Ilham, R. (2018a). Improve Quality Of E-Loyalty In Online Food Delivery Services : A Case Of Indonesia. Journal of Theoretical and Applied Information Technology, 96(15), 4760-4769.

Ilham, R. (2018b). The Impact of Organizational Culture and Leadership Style on Job Satisfaction and Employee Performance. Journal of Advanced Management Science, 6(1), 50-53. https://doi.org/10.18178/joams.6.1.50-53

Jay Galbraith. (1977). Organization Design. Addison-Wesley.

Joseph F. Hair, J., Ringle, C., \& Sarstedt, M. (2011). PLS-sem: Indeed a silver bullet. The Journal of Marketing Theory and Practice (Vol. 19). https://doi.org/10.2753/MTP1069-6679190202

Kotler, P., \& Keller, K. L. (2015). Marketing Management, Global Edition (15th ed.). Pearson.

Liang, H., Wang, M., Wang, J., \& Xue, Y. (2018). Computers in Human Behaviour How intrinsic motivation and extrinsic incentives affect task effort in crowdsourcing contests : A mediated moderation model. Computers in Human Behaviour, 81, 168-176. https://doi.org/10.1016/j.chb.2017.11.040

Liberty, J. V., \& Prewitt, J. (1999). Professional leadership education: an analysis. Career Development International, 4(3), 155-162. https://doi.org/10.1108/13620439910262831

MacArthur, J. (1998). In the Footsteps of Faith. New York USA: Crossway Books.

Markow, F., \& Klenke, K. (2005). The effects of personal meaning and calling on organizational commitment: An empirical investigation of spiritual leadership. International Journal of Organizational Analysis, 13(1), 8-27. Retrieved from http://www.emeraldinsight.com/doi/abs/10.1108/eb028995

Markow, F., \& Klenke, K. (2005). The Effects Of Personal Meaning And Calling On Organizational Commitment: An Empirical Investigation Of Spiritual LEADERSHIP. International Journal of Organizational Analysis, 13(1), 8-27. https://doi.org/10.1108/eb028995

Meyer, J. P., \& Allen, N. J. (1991). A Three-Component Model Conceptualization of Organizational Commitment. Human Resource Management Review, 1(1), 61-89. https://doi.org/10.1016/1053-4822(91)90011-Z

Monecke, A. and Leisch, F. (2012). semPLS : Structural Equation Modeling Using Partial Least Squares. Journal of Statistical Software, 48(3), 1-32. https://doi.org/10.1108/EBR-10-20130128 
Nyhan, R. C. (2000). Changing the Paradigm. The American Review of Public Administration, 30(1), 87-109. https://doi.org/10.1177/02750740022064560

Osa, I. G., \& Amos, I. O. (2014). The Impact of Organizational Commitment on Employees Productivity: A Case Study of Nigeria Brewery, PLC. International Journal of Research in Business Management (IMPACT : IJRBM), 2(9), 2347-4572.

Pfeffer, J. (2003). Business and the Spirit. Management Practices That Sustain Values. Handbook of Workplace Spirituality and Organizational Performance, 29-45.

Piryaei, S., \& Zare, R. (2013). Workplace Spirituality and Positive Work Attitudes: the Moderating Role of Individual Spirituality. Indian Journal of Economics and Development, 1(4), 91-97. Retrieved from http://indjst.org/index.php/ijed/article/view/33677

Robbins, S. (2013). Organizational Behaviour. Zhurnal Eksperimental'noi i Teoreticheskoi Fiziki. https://doi.org/10.12737/4477

Roy F. Baumeister. (1991). Meanings of Life. New York: Guilford Press.

Samekto, A., Ilham, R., Djuwari, \& Effendi, M. B. (2017). Spiritual Leadership As A Model For Organization Commitment And Productivity ( A Study of Private University In Indonesia ), $16-20$.

Schein, E. H. (1990). Organizational Culture. American Psychologist, 45(2), 109-119. https://doi.org/10.1037/0003-066X.45.2.109

Seligman, M. E. P., \& Csikszentmihalyi, M. (2000). Positive psychology: An introduction. American Psychologist. https://doi.org/10.1037/0003-066X.55.1.5

Snyder, C. R., \& Ingram, R. E. (2000). Handbook of Psychological Change: Psychotherapy Processes $\&$ Practices for the 21st Century. New York: Wiley.

Sosik, J. J., \& Godshalk, V. M. (2000). Leadership styles, mentoring functions received, and jobrelated stress: a conceptual model and preliminary study. Journal of Organizational Behaviour, 21(4), 365-390. $\quad$ https://doi.org/https://doi.org/10.1002/(SICI)10991379(200006)21:4<365::AID-JOB14>3.0.CO;2-H

Thayib. (2013). SPIRITUAL LEADERSHIP, KEPUASAN KERJA, DAN PRESTASI KERJA. Al'AdâLah, 16(2), 351-382.

Turban, E., McLean, E., \& Wetherbe, J. (2001). Information Technology for Management. Improving Quality and Productivity.

Wnuk, M., Marcinkowski, J. T., \& Fobair, P. (2012). The relationship of purpose in life and hope in shaping happiness among patients with cancer in Poland. Journal of Psychosocial Oncology, 30(4), 461-483. https://doi.org/10.1080/07347332.2012.684988 